\title{
AN ASSESSMENT OF WOMEN ENTREPRENEURSHIP PERFORMANCE IN NIGERIA
}

\author{
SAFIYYAH MUHAMMAD ALIYU \\ Department of Business Administration \\ Faculty of Management Sciences \\ University of Abuja, Nigeria
}

\begin{abstract}
Entrepreneurial activities are important factors in creating and increasing employment opportunities and fuelling economic growth. Entrepreneurship is an important source of job creation and opening career opportunities for both women and men. However, women are less likely to have successful enterprises or businesses than men. This paper is aimed at assessing women entrepreneurship in Nigeria: their present state of involvement in comparison to the male entrepreneurs, their challenges, contributions and performance in the formal and informal business sector of the economy. The paper employed the descriptive method of analysis. An inductive methodology involving observation, collection of secondary data and the analysis of such data was employed. To this end, a lot was devoted to the presentation and analysis of data obtained from the Small and Medium Enterprise Development Agency of Nigeria, the National Bureau of Statistics and the Federal Office of Statistics. It was discovered that women participate more in the micro business (informal sector) constituting $42.1 \%$ of the ownership structure. Their performance constitutes $13.57 \%$ in the formal sector as against the male entrepreneurs at $86.43 \%$. Their poor performance and contribution are a result of the constraints they face. It was also discovered that their performance was higher in the Trade and Agricultural Sector in 1997 but higher in the Education and Service Sector by 2012. Among others, it is recommended that good practice in supporting women entrepreneurship should be initiated by the government in the form of training courses, advisory services or creating awareness campaigns.
\end{abstract}

Keywords: Entrepreneurship, women entrepreneurs, entrepreneurial activities, economic growth.

\section{Introduction}

An important part of capitalizing on human potential lies in fostering entrepreneurship. The important role that small businesses and entrepreneurship play in stimulating economic activity, creating jobs, alleviating poverty and uplifting living standards, has been recognized internationally as well as in Africa (Van Vuuren \& Groenewald, 2007). Women entrepreneurship can only contribute to eradicating abject poverty and uplifting the standards of living. Unfortunately, women have formed a substantial majority of the poor.
Statistics show that women are poorer than men. The UNDP (1995) estimated that, about 60 per cent of the world-poorest are women. Women are poorer because they are more vulnerable economically. Rais (2002) maintained that globally, women entrepreneurs constitute a disadvantaged group of economic agents. The Canadian International Development Agency (CIDA) in its report on Gender Situation Assessment and Analysis (GSAA) (2006) asserts that of the $70 \%$ of the population estimated to be living below poverty line over $65 \%$ are projected to be women. 
Entrepreneurship development therefore is a crucial tool for women's economic empowerment. Women's performance in entrepreneurship may not have been felt over the years. The marginalization of women enterprise and its beneficial impact on the economy as a whole have long been recognized (SMEDAN, 2007). According to Maas and Herrington (2006), the growth in a trial number of female entrepreneurs outnumber male entrepreneurs. There is clear evidence that enabling women to develop their skills and qualifications and to join the labour market boosts incomes and well-being throughout society. In particular, educating girls boosts prosperity. In the same vein, Goldberg (2010) said that while at least half of the brainpower on earth belongs to women, women remain perhaps the world's most underutilized resource. He argues that not only is equal opportunity in the area of entrepreneurship not a reality, its absence is a drag on growth, development and poverty alleviation.

It is widely recognized that entrepreneurial activity is strongly associated with increased GDP and hence welfare - suggesting a need to understand the nature of these activities (McClelland et al., 2005). The findings of Halkias et al. (2011) revealed that no or few significant differences exist between male and female business owners or managers once they have already started an enterprise and this indicates that Africa does have sizeable hidden growth potential in its women.

However, women are less likely to have successful enterprises or businesses than men (Minniti \& Arenius, 2003). Studies have shown that they constitute a greater proportion of the Nigerian population; their participation in entrepreneurial ventures, if fully exploited will bring about significant contribution in the recovery process of a depressed economy.

To this end, the researcher aimed to find answers to the following questions:

1. To what extent are Nigerian women involved in entrepreneurial activities?
2. To what extent do they contribute in the formal and informal business sector of the economy?

3. What are some of the challenges faced by women entrepreneurs in Nigeria?

The purpose of this study therefore, is to assess women entrepreneurship in Nigeria: their present state of involvement in comparison to the male entrepreneurs, their challenges, contribution and performance in the formal and informal business sector of the economy. The paper is organized as follows: section 2 outlines the literature review and theoretical framework of the study. Section 3 describes the methodology of the study. Analysis and results are presented in sections 4 . Conclusion, recommendations and implication form section 5 .

\section{Literature Review and Theoretical Framework}

\section{Entrepreneurship, entrepreneurs and women entrepreneurs}

Hossain et al. (2009) asserted that it is difficult to define entrepreneurship as entrepreneurial activities substantially vary from one to another. In considering the term in a general sense it involves sacrifice, creativity and risk-taking on the part of the business owner. Nickels et al. (2002) defined entrepreneurship as accepting the risk of starting and running a business. In the same vein, Ajiye (2005) defined entrepreneurship as the willingness and ability of an individual to seek out investment opportunities in an environment and be able to establish and run an enterprise based on these factors successfully. An entrepreneur is a promoter of an enterprise. A person with a vision or idea who puts together resources to realize those visions and ideas that result in them earning a living and helping the society, is being enterprising. If a woman does this, she is an entrepreneur. Kumar (2006) viewed woman entrepreneur as a woman or a group of women who initiate, organize and run a business 
enterprise. While Jayalakshmi (2009) saw a woman entrepreneur as a person who accepts challenging roles to meet her personal needs and become economically independent. She further added that a strong desire to do something positive is an inbuilt quality of entrepreneurial women who are capable of contributing values to both family and social life.

Kiyosaki (1993) proved with statistical data in the United States that women were better investors than men. In the same vein, the National Association of Investors Corporation (NAIC) (2000) study found that women-only clubs achieved average annual returns of 32 per cent since 1951 versus 23 per cent for menonly investment clubs. The verdict is women know how to handle money and can be greater entrepreneurs than men if the various obstacles to development are removed or minimized. This implies that women perform better where necessary business resources are available. However, studies have shown that they are faced with overwhelming challenges as they are often marginalized. According to a demographic and health survey, carried out by the National Planning Commission (1996), female-headed households constituted 23 per cent in south-east Nigeria, 19 per cent in south-west Nigeria, 6 per cent in the north-east, and 5 per cent in the northwest. This implies that many Nigerian women entrepreneurs largely live in poverty (National Planning Commission, 1996; Eyaefe, 2008). This also means that they virtually initiate and execute numerous money-yielding projects to be able to ensure the survival of their families. Similarly, Wilma and Allen (1998) maintained that the global economic development resources and property ownership are concentrated in the hands of more men than women. The study done by Dejardin and Awad (1995), pointed to the fact that the access of women entrepreneurs to credit was greatly restricted. Women entrepreneurs have more difficulties in obtaining credit facilities (Okojie, 2002), even though they perform better in loan-repayment tendency (Achoja \& Ideh, 2005).

\section{What Motivates Women Entrepreneurs?}

Botha (2006) recommended that it was important to determine the factors that motivate women to start their own businesses. This knowledge regarding the profile of the woman entrepreneur might enable policy-makers to create an encouraging environment for women entrepreneurs to start their own businesses. Heilman and Chen (2003) as well as Botha (2006) argued that various push-and-pull factors exist that can motivate women to start their own businesses. Maas and Herrington (2006) defined push factors as the more negative factors, such as unemployment and retrenchment, which force people to become entrepreneurial in order to survive. They regard pull factors to be the more positive factors, such as government support and role models, which might influence people to choose entrepreneurship as a career option. Ghosh and Cheruvalath (2007) found that only one-fifth of women were drawn into entrepreneurship by pull factors. The rest are forced into entrepreneurship by push factors.

Nzelibe (2006) asserted that the factors that are identified to motivate male entrepreneurs are not different from those that motivate women entrepreneurs. She identified them as follows: need for achievement; need for independence; risk-taking ability; desire for responsibility; provision for job opportunities for self; family members and others; economic power to control business and employees; influence of the success of others; and retirement plan and displacement from the workplace or do not have skills to obtain paid jobs. On the other hand, in the study conducted by Singh et al. (2011) where these factors were categorized and data were collected from 300 small scale Nigerian women entrepreneurs to ascertain what motivated them to become entrepreneurs, the analysis revealed that challenge, self-achievement, desire for social recognition, desire to earn extra income, deregulation policies by the Nigerian government were the variables that appeared to be significant while the desire to build equity for retirement, to change careers, or the fact that women could not 
get a job or fear of unemployment do not play any significant role in their decision to become entrepreneurs.

Singh et al. (2011) further predicted that the availability of the benefits of education and family capital would help precipitate Nigerian women's decision to enter self-employment. This is consistent with other research in the context of Africa (McClelland et al., 2005) where family commitments, particularly a desire to create a better environment for family members, emerged as a strong motivating factor to entrepreneurship. Similarly, the study of Hossain et al. (2009) showed that factors such as women membership in professional associations, advocacy and decision-making (self-fulfillment), and woman knowledge were the main factors that influenced women decisions to become self-employed.

\section{Challenges Faced by Women Entrepreneurs in Nigeria}

In spite of their contribution to the economic growth, women still face numerous challenges in engaging in entrepreneurial activities in Nigeria. Some of these challenges are:

\section{Discriminations, Social and Cultural Restrictions:}

Cultural beliefs and traditions still remain as obstacles for women to be entrepreneurs in Nigeria. As in many African countries, Nigeria holds conservative values and traditional customs in doing business activities. Entrepreneurial activity or business is recognized to be an occupation for men, whereas women should stay at home. Nigeria is a patriarchal society. Mordi et al. (2010) opined that gender expectations are that women should be humble and modest and, through the priority given to their roles as wives and mothers, they should take a lesser role in business or incoming activities. The asymmetry and ascendancy of males over females in the labour market are clearly seen in patriarchal communities, whereas in Nigeria there is a large power distance and high masculinity (Hofstede, 1980; Mordi, Simpson, \& Singh, 2010). Such cultural beliefs create barriers for
Nigerian women entrepreneurs. In Nigerian culture, the traditional female role is still highly regarded, and such qualities as subservience, supportiveness, and submissiveness meet with approval (Woldie \& Adersua, 2004). In addition to the aforementioned issues, women also hold a lot of family responsibilities. Okafor and Amalu (2010) observed that women were groaning under unjust culture, beliefs and overbearing influence of a male-dominated society especially in Nigeria where women are denied access to property and land ownership.

Female business owners are often subjected to gender-related discrimination. Abor and Biekpe (2006) emphasized that this discrimination against women seems to be even worse in subSaharan African countries, such as Ghana, where the financial sector is male-oriented. The argument is further supported by Marlow (1997), who commented that discrimination remained a problem for women in selfemployment, for example, they experienced particular difficulties in gaining bank finance for their ventures. Sani (2001) noted that in Africa, cultural myths contributed to relegating women to the background. The belief has been that we are living in "a man's world" and men continue to take credit for creating wealth; these women work under hostile and discriminatory socioeconomic and cultural environment. This could restrict their participation in entrepreneurship.

Lack of Access to Finance: This is a major challenge for most businesses in Nigeria but the situation is far worse for women entrepreneurs. The Canadian International Development Agency (CIDA) (2006) reported that 70 per cent of the population is estimated to be living below poverty; over $65 \%$ is projected to be women. It is statistically shown that women, constituting half of the Nigerian population, "have remained in the bottom 30 per cent of the poorest citizens" (Woldie \& Adersua, 2004). Because of poverty, women often do not have the capital required to start their businesses. According to the report Framework for a Strategy to Support Women Entrepreneurs in Nigeria, "women typically do not possess the kind of tangible assets 
banks require in order to lend money" (cited in Halkias et al., 2011). Even though Nigerian women approximately own 25-30 per cent of the registered businesses, only 10-15 per cent have access to bank credits (Halkias et al., 2011). The difficulty of limited access to credit negatively affects their effective participation in the economic growth of Nigeria.

Lack of Education and Experience: Most Nigerian women entrepreneurs, either those operating in formal or informal businesses, lack entrepreneurial knowledge and skills. Fasokun (2000) acknowledged that education not only provides basic knowledge and skills to improve health and livelihood, but it also empowers women to take their rightful place in the society and the development process. It is a fact that people with better educational background and adequate training perform better than those that are ignorant. The human capital theory posits that individuals with higher quality human capital achieve higher performance in executing relevant tasks (Becker, 1975). Snell and Dean (1992) defined human capital as the knowledge and skill that assist people in successfully discovering and exploiting opportunities (OECD, 2004). Rural women in Nigeria are mostly affected by this factor. They lack education and experience in entrepreneurship.

Women's Family Role: This is a factor that affects women all over the world. Women have the obligations to cater for their families which tend to affect their ability to concentrate in other activities. In Africa, the situation is not any different. Woldie and Adersua (2004) said "in Nigerian culture, the traditional female role is still highly regarded, and such qualities as subservience, support, and submissiveness meet with approval". In addition, women also hold a lot of family responsibilities. Since they are believed to be the ones who take care of children, becoming entrepreneurs and at the same time performing womanly tasks becomes a great challenge. Research by the World Bank (2000) indicated that gender inequalities in developing countries inhibit economic growth. There is a correlation between gender discrimination and greater poverty, slower economic growth, weaker governance, and a lower standard of living of the people. However, the environment in Nigeria where women are still expected to perform their social functions sometimes detracts from these achievements. In other words, gender stereotypes and expectations remain mired in tradition and will require further action on the part of the government and the society to break (Iheduru, 2002).

Despite the fact that women entrepreneurs face challenges, they are still able to achieve substantial firm growth. For example in some developing economies like Ethiopia, Tanzania and Zambia as surveyed by ILO as well as in more developed economies such as the United States, the ability of women entrepreneurs to achieve firm growth and attract venture capital has now become so important that it has become a topic for systematic research (OECD, 2004). The benefits derivable from empowering the womenfolk are not far-reaching, starting with family advancement and eventually touching on the national and global economic advancement. Kiyosaki (1993) asserted that it is the nation that blends the strengths of women and men that will lead the world in development in the field of agriculture and other sectors.

\section{Women Entrepreneurship Development in Nigeria}

Women's entrepreneurial activities will serve as a means of livelihood and survival for women and their families; this will in turn contribute to the growth of the economy. The Nigerian government's policy of promoting entrepreneurship dated back to the early 1970s. The hope of promoting small-scale enterprises to stimulate entrepreneurship was documented in the 2nd National Development Plan (197074) and the policies have continued till date through various strategies of technical, financial and management of the small-scale industries. Several government agencies have been set up to ensure the development of entrepreneurial activities in Nigeria. The Federal Government's 
concern for addressing the problem of mass unemployment in the mid-1980s spurred the setting up of the National Directorate of Employment (NDE) in 1986 and the Work For Yourself Programme (WFYP) in 1987 was set up as a means to reduce the problem of mass unemployment amongst youth. The National Youth Service Corps (NYSC) is another youth empowerment programme. The categories of development programmes are as follows: General Entrepreneurship Programme (GEDP), Youth Entrepreneurship Development Programme (YEDP), Rural Enterprise Development Initiative (REDI) and Women Entrepreneurship Development Programme (WEDP).

The Women Entrepreneurship Development Programme (WEDP) is targeted at the women and it is aimed at transforming the women into successful entrepreneurs. The programme seeks to economically empower the Nigerian women. Another development programme tailored towards assisting Nigerian women is the Rural Women Enterprise Development Programme. Its objective is to explore and exploit the latent potentials of the rural women who are mostly faced with overwhelming challenges (SMEDAN, 2012).

Singh et al. (2011) noted that in order to encourage female entrepreneurs, the Nigerian government in 1987 introduced the Better Life for Rural Women Programme and the Family Support Programme. These programmes were partly aimed at encouraging female entrepreneurs by promoting education, health and economic development of women. It made unprecedented contribution to women through the cooperative organizations. A number of Non-Governmental Organizations (NGOs) also came up to promote entrepreneurship development. Prominent amongst them is the Country Women Association of Nigeria (COWAN). It targets rural and urban poor women through cooperative rather than individual memberships and aims to promote the welfare of women in agricultural and economic decision-making so as to effect self-reliance and sustainable development (Halkias et al., 2011).
The majority of these development programmes in Nigeria have failed in terms of the execution and meeting of their objectives. Dionco-Adetayo et al. (2005) concluded that these programmes largely failed to deliver the benefits promised and they were not sustained by recent Nigerian governments. Inang and Upong (1999) observed that several government organs have been established to channel funds to small and medium industries with limited results (Inegbenebor, 2005). In the same vein, Ekpenyong, (1988) asserted that the delivery of entrepreneurship programmes in Nigeria was poor as a variety of teachers were assembled and given materials hurriedly written (Inegbenebor, 2005). Another view is that women are not even included in the development programmes. Halkias et al. (2011) observed that policies introducing economic enhancement programmes were reported to be gender-blind, with women not explicitly included in them.

\section{Theoretical Framework}

This study is anchored upon the liberal feminist theory and the social feminist theory. The liberal feminist theory is based on the premise that women are facing overt discrimination, for example, education and/ or business experience (Fischer et al., 1993). In entrepreneurship research this approach is seen in studies of potential discrimination in the way that lenders deal with women entrepreneurs.

The social feminist theory is based on the socialist process such as family setting, social values, norms, experience, educational aspirations and expectations (Fischer et al., 1993). The theory suggests that due to differences in early and ongoing socialization women and men do differ inherently. However, it also suggests that this does not mean women are inferior to men, rather women's lesser experience in working in similar firms and in helping to start-up businesses may help to explain their smaller size, slower income growth and lesser sales per employee of their firms. The difference noted above may be referred to either a situational (structural) liberal feminism - or a dispositional perspective 
(related to work, family or social life) - social feminism - that affects women's ability to start and grow their businesses.

\section{Methodology}

The study relied on secondary data obtained from the Small and Medium Enterprise Development in Nigeria (SMEDAN), the National Bureau of Statistics (NBS) and the Federal Office of Statistics. Data were also obtained from relevant books and the internet. The study employed a descriptive method of analysis.

\section{Data Presentation and Analysis}

Table 1

Percentage Distribution of Persons Employed in Industry, 1997

\begin{tabular}{lcc}
\hline Industry & Male & Female \\
\hline Agriculture & 63.0 & 47.8 \\
Mining & 0.1 & 0.0 \\
Manufacturing & 4.0 & 3.7 \\
Utility & 1.0 & 0.0 \\
Construction & 1.0 & 0.1 \\
Trade & 12.0 & 37.6 \\
Transportation & 5.0 & 0.1 \\
Finance & 0.8 & 0.3 \\
Service & 14.0 & 10.2 \\
\hline Total & 100 & 100 \\
\hline
\end{tabular}

Source. Federal Office of Statistics (1997).

The above table shows that women employment constituted $47.8 \%$ in the agricultural sector, $37.6 \%$ in trade and $10.2 \%$ in the service industry. This reveals that women's performance is higher in these sectors compared to other sectors such as utility, mining, construction and transportation. Their high performance could be as a result of small investment requirements and their low performance in other sectors could be as a result of the challenges they face in accessing adequate finance, education, stereotyping and discrimination. However, it is interesting to note that women performance in trade is higher than that of the male constituting about $37.6 \%$ as against $12 \%$ for males. Trade in Nigeria is usually at a micro or small scale requiring small cash investment for startup and ample time available for the business owner; hence the possibility of women performing better than men in this industry is high.

The above table reveals that women participated the least in the mining and quarrying sector; they accounted for just $1.85 \%$. The building and construction sector accounted for $2.63 \%$, and this was closely followed by the transport, storage and communication sector which accounted for $2.74 \%$ and the manufacturing sector accounted for $6.9 \%$ in the ownership structure as against male entrepreneurs who accounted for $98.15 \%, 97.37 \%, 97.26 \%$ and $93.09 \%$ respectively. This could be as a result of the high requirement for capital to start up such businesses and the lack of access to needed finances. The low performance in the other sectors such as financial intermediation (7.14\%), real estate $(9.33 \%)$, agriculture $(7.69 \%)$, health and social work $(10.57 \%)$ could be as a result of the lack of education, inability to access land and other agricultural inputs. When compared to their male counterparts who seem to be well placed in the sectors at $92.86 \%, 90.67 \%, 92.1 \%$ and $89.43 \%$ respectively it can be seen that they have better opportunity for education, and easier access to landed properties. Of all the sectors, women seem to be better placed in the education sector accounting for $37.88 \%$ and the service sector at $37.23 \%$. This could be as a result of easier startup requirements especially for the service sector. Though, the male entrepreneurs are still leading in these industries at $62.12 \%$ and $62.77 \%$, the female contribution is most felt in these sectors. 
Table 2

Gender of Owner (Sole proprietors) in Nigeria

\begin{tabular}{lrrrrr}
\hline \multirow{2}{*}{ Sector } & \multicolumn{2}{c}{ Male } & \multicolumn{2}{c}{ Female } & Total \\
\cline { 2 - 6 } & Number & Percentage & Number & Percentage & \\
\hline $\begin{array}{l}\text { Agriculture, hunting, forestry and } \\
\text { fishing }\end{array}$ & 488 & 92.1 & 41 & 7.69 & 529 \\
Mining and quarrying & 96 & 98.15 & 2 & 1.85 & 98 \\
Manufacturing & 3,565 & 93.09 & 265 & 6.91 & 3,830 \\
Building and construction & 83 & 97.37 & 2 & 2.63 & 86 \\
$\begin{array}{l}\text { Wholesale and retail trade; repair } \\
\text { of motor vehicles and HH }\end{array}$ & 2,576 & 89.51 & 302 & 10.49 & 2,878 \\
Hotel and restaurants & 1,099 & 76.56 & 337 & 23.44 & 1,436 \\
$\begin{array}{l}\text { Transport, storage and } \\
\text { communication }\end{array}$ & 386 & 97.26 & 11 & 2.74 & 397 \\
Financial intermediation & & & & & \\
Real estate, renting and business & 468 & 90.67 & 48 & 9.33 & 516 \\
activities & & & & & \\
Education & 687 & 62.12 & 419 & 37.88 & 1,106 \\
Health and social work & 1,377 & 89.43 & 163 & 10.57 & 1,540 \\
$\begin{array}{l}\text { Other community, social and } \\
\text { personal service activities }\end{array}$ & 301 & 62.77 & 179 & 37.23 & 479 \\
\hline Total & 11,383 & 86.43 & 1,787 & 13.57 & 131,169 \\
\hline
\end{tabular}

Source. SMEDAN \& NBS, 2012.

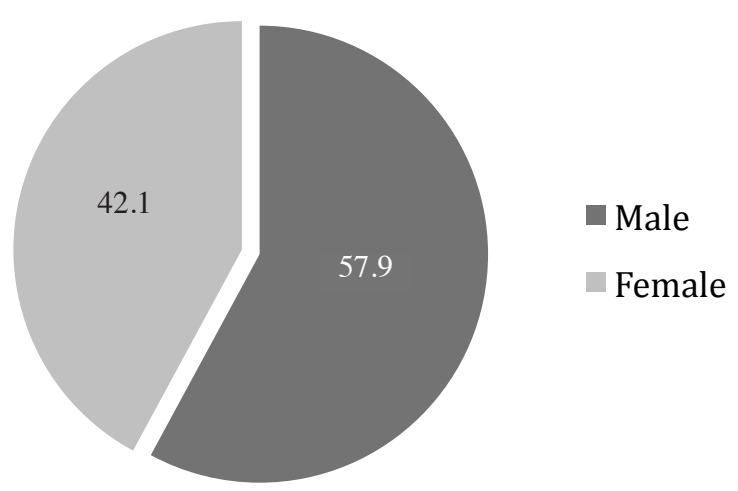

Source. SMEDAN \& NBS (2012).

Figure 1. Pie chart showing distribution of the Informal Business Sector by Gender. 
The above chart shows that female entrepreneurs accounted for $42.1 \%$ in the ownership structure as against $57.9 \%$ for males in the micro enterprises (informal business sector). This informal sector is easy to set up as it requires little startup capital and minimal paper work as company registration requirements here are not tedious compared to the formal sector where company registration requirements are more intense. It is necessary to note that income and productivity in this sector are low. For the formal sector, which comprises the small and medium enterprises, females account for $13.57 \%$ as against $86.43 \%$ for males.

\section{Conclusion and Recommendation}

This study set out to assess the challenges, contributions and performance of female entrepreneurs in Nigeria in comparison with male contributions. Drawing on the liberal feminist theory and the social feminist theory and based on secondary data from SMEDAN, NBS and the Federal Office of Statistics on small-scale entrepreneurs in Nigeria we can conclude that women are more involved in micro enterprises (informal business sector) because it is easier for them to start up but others are drawn into the business sector by the push factors. The informal sector includes organizations with such characteristics as low capital, ease of entry and preponderance of family ownership (Kitching and Woldie, 2004). However, men still account for the higher ownership structure in the informal sector. Their contribution at the formal sector is quite low. This finding is consistent with the findings of Minniti \& Arenius (2003). In engaging in entrepreneurial activities, women face more challenges than men. This accounts for their low contribution and performance. Dionco-Adetayo et al. (2005) observed that it is evident that for women who were found to have been engaged in small-scale business, a lot of constraints have hindered their economic participation. With these challenges in being self-employed, they basically engage in entrepreneurial activities to ensure the survival of their families. The implication is that it will negatively affect their entrepreneurial performance in Nigeria.

\section{Implication of the Study}

Results from the study imply that women entrepreneurship development programmes set up in Nigeria are yet to achieve their objectives of promoting women entrepreneurship performance in Nigeria as their performance is still low. Where women entrepreneurship is promoted, the implication is that the businesses of these women will create employment for youths thereby making them productive and social vices in the country will be reduced. The products and services rendered by these women will also contribute to the growth of the economy. Hence, the government, NGOs and other stakeholders can go a step further and determine adequate measures to enhance the performance and contributions of women entrepreneurs and provide them with the necessary assistance to get them started on the entrepreneurship route.

Therefore, it is recommended that the Nigerian government should create institutions that are oriented towards assisting the entrepreneurial activities of women and its objectives should be followed through. The existing entrepreneurial development programmes set up by the government should try to reach out more to encourage women to partake and take advantage of these available development schemes. For the Nigerian women entrepreneurs to have a stronger voice in the pursuit of their rights from stakeholders, they should organize themselves into associations for the promotion, development and support of women entrepreneurship. Government, non-governmental organizations and other stakeholders should encourage rural women by providing periodic education, enlightenment and training through seminars and conferences at little or no cost to give them insight and the knowledge about starting their own business and how to secure loans and startup capital.

\section{Recommendation for Future Research}

This study's analysis revealed that empirical studies are needed the determine the major 
challenges faced by Nigerian women entrepreneurs which result in their lower performance in the formal sector. Future research initiatives are also required to explore those factors affecting women's entrepreneurship development in Nigeria. Investigations into the contribution of some business development organizations such as the government, NGOs, private sector, membership organizations, and donors towards the development of women entrepreneurship should be explored.

\section{References}

Abor, J., \& Biekpe, N. (2006). SME's access to debt finance: A comparison between male-owned and female-owned business in Ghana. The International Journal of Entrepreneurship and Innovation, 7(2), 105-112.

Achoja, F. O., \& Ideh, V. (2005). Performance of rural women farmers in micro credit repayment: Evidence from coastal area of Delta State Nigeria. In Ogisi D.O. Okuneye, B. P. and Oyaide, W. J. (Eds.), Economic Reforms and Management of Nigeria Agriculture, (pp.125-133). Proceedings of Farm Management Association (FAMAN) at the 19th Annual Conference held at Delta State University, Asaba Campus.

Adeleja, M. A. (2004). An address by the director general of SMEDAN at its official flag-off of National Survey of Micro Small and Medium Enterprises in all Local Governments of the Federation, Nigeria.

Ajiye, A. (2005). New era entrepreneurship. Soma Associate, Lagos, Nigeria.

Botha, M. (2006). Measuring the effectiveness of the women entrepreneurship programme, as a training intervention, on potential, start-up and established women entrepreneurs in South Africa (Unpublished $\mathrm{PhD}$ thesis). University of Pretoria, South Africa.
Dejardin, A. K., \& Awad, A. I. (1995). Gender, policy and business. Retrieved from http://www.transcampus.org/

Dionco-Adetayo, E. A., Makinde, J. T., \& Adetayo, J. O. (2005). Evaluation of policy implementation in women entrepreneurship development. Retrived from www.womenable.com/userfiles/ downloads/ICSB_bestWOBpaper_2005. pdf.

Eyaefe, J. A. (2008). Empirical study of poverty status of small scale agribusiness entrepreneurs in Warri metropolis of Delta State (Unpublished B. Agric. Project work). Department of Agricultural Economics and Extension, Delta State University, Asaba Campus.

Fasokun, T. O. (2000). The role of education in poverty eradication: An education for millenium development. Ibadan: Spectrum Books Limited.

Fischer, E. M., Reuber, A. R., \& Dyke, L. S. (1993). A theoretical overview and extension of research on sex, gender and entrepreneurship. Journal of Business Venturing, 8(2), 151-168.

Ghosh, P., \& Cheruvalath, R. (2007). Indian female entrepreneurs as catalysts for economic growth and development. The International Journal of Entrepreneurship and Innovation, 8(2), 139-148.

Goldberg, R. L. (2010). Women and entrepreneurship (Part I). Retrieved from http://www.theglobalist.com/

Halkias, D., Nwajiuba, C., Harkiolakis, N., \& Caracatsanis, S. M. (2011). Challenges facing women entrepreneurs in Nigeria. Management Research Review, 34(2), 221-235.

Heilman, M. E., \& Chen, J. J. (2003). Entrepreneurship as a solution: The allure of self-employment for women and minorities. Human Resource Management Review, 13(2), 347-364.

Hofstede, G. (1980). Culture's consequences: International differences in work related values. London: Sage. 
Hossain, A., Naser, K., Zaman,A., \& Nuseibeh, R. (2009). Factors influencing women business development in the developing countries: Evidence from Bangladesh. International Journal of Organizational Analysis, 17(3), 202-224.

Iheduru, N. G (2002, July). Women entrepreneurship and development: The gendering of microfinance in Nigeria. A paper presented at the 8th International Interdisciplinary Congress on Women, Makerere University, Kampala-Uganda.

ILO. (2006). Women's entrepreneurship development: Capacity building guide. International Labour Office, Geneva.

Inegbenebor, A. U. (2005). Education for enterpreneurship: Experience at the University of Benin. A paper presented at the inaugural conference of Academy of Management, Nigeria.

Jayalakshmi, G. (2009). Women entrepreneurship and changing role of women. Retrieved from http://www.articlebase.com.

Kitching, B. M., \& Woldie, A. (2004). Female entrepreneurs in transitional economics: A comparative study of businesswomen in Nigeria and China. Proceedings of Hawaii International Conference on Business. Honolulu, Hawaii, USA.

Kiyosaki, T. R. (1993). If you want to be rich and happy, don't go to school. Texas: Aslan Publishing.

Kumar, D. M. (2006). Problems of women enterprises in India. Retrieved from www. indiamba.com/

Maas, G., \& Herrington, M. (2006). Global entrepreneurship monitor (GEM). South African report. University of Cape Town, Cape Town, South Africa.

McClelland, E., Swail, J., Bell, J., \& Ibbotson, P. (2005). Following the pathway of female entrepreneurs: A six-country investigation. International Journal of Entrepreneurial Behaviour and Research, 11(2) , 84-107.

Marlow, S. (1997). Self-employed women: New opportunities, old challenges?
International Journal of Entrepreneurship and Regional Development, 9(3), 199-210. Minniti, M., \& Arenius, P. (2003). Women in entrepreneurship: The entrepreneurial advantage of Nations. First Annual Global Entrepreneurship Symposium. Ministry for Economic Development (2004) SMEs in New Zealand, Structure and Dynamics.

Mordi, C., Simpson, R., \& Singh, S. (2010). The role of cultural values in understanding the challenges faced by female entrepreneurs in Nigeria: Gender in management. An International Journal, 25(1), 5-21.

Nickels, W., McHugh, J., \& McHugh, S. (2002). Understanding business (6th ed.). New York: Mc Graw Hill.

Nzelibe, G. C. (2006). Entrepreneurship and management of small scale business. Nigeria: Optimal Publishers.

National Planning Commission. (1996). Annual report. Retrieved from www.npc.gov.ng

OECD. (2004). Women entrepreneurship: Issues and policies. 2nd OECD Conference of Ministers responsible for Small and Medium Sized Enterprises. Istanbul, Turkey.

Okafor, C., \& Amalu, R. (2010). Entrepreneurial motivations as determinants of women entrepreneurship challenges. Economic Sciences Series, LXII (2), 67-77.

Okojie, C.E.E. (2002). Globalization and the women's enterprises: Opportunity and challenges. UNIFEM Women Entrepreneurs Forum. Lagos, Nigeria.

Rais, R. B. (2002). Gender discrimination. Retrieved from www.http.sachet.org.pk/

Sani, H. (2001). Women and national development. Ibadan: Spectrum Books.

Singh, S., Simpson R., \& Mordi, C. (2011). Motivation to become an entrepreneur: A study of Nigerian women decision. African Journal of Economic and Management Studies, 2(2), 202-219.

SMEDAN. (2007). National policy on micro, small and medium scale enterprises. Retrieved from http://www.smedan.gov. ng/ 
SMEDAN \& NBS. (2012). Survey report on micro, small and medium enterprises (MSMEs) in Nigeria. National MSME collaborative survey.

UNIDO. (1995). Women, industry and entrepreneurship. Women in industry series, Vienna, Australia. Retrieved from http://www.unido.org/

Van Vuuren, J. J., \& Groenewald, D. (2007). A critical analysis of the influence of start-up factors in small businesses and entrepreneurial ventures in South Africa. Acta Commercii, 7, 269-280.

Wilma, G., \& Allen, J. (1998). Gender sensitivity. UNESCO Publication.

Woldie, A., \& Adersua, A. (2004). Female entrepreneurs in a transitional economy: Businesswomen in Nigeria. International Journal of Social Economics, 31(1/2), 7893.

World Bank. (2000). Nigeria at a glance. The World Bank, Washington D. C. 